\title{
Pemanfaatan dan Pengelolaan Google Classroom Sebagai Media Pembelajaran dan Pengajaran Daring Bagi Guru-Guru SMP
}

\author{
Awaludin Fitra $^{1)}$, Martua Sitorus ${ }^{2)}$, Dedi Candro Parulian Sinaga ${ }^{3)}$, Endra A. P. Marpaung ${ }^{4)}$ \\ ${ }^{1), 2), 3), 4)}$ Program Studi Teknik Informatika, STMIK Pelita Nusantara, Medan, Sumatra Utara \\ Corresponding Author:Awaludin Fitra, luthgayo1983@gmail, Martua Sitorus, \\ Martuasitorus84@gmail.com, Dedi Candro Parulian Sinaga, dedisinaga27@gmail.com, Endra A.P. \\ Marpaung, indra_only85@ymail.com
}

\begin{abstract}
Abstrak: Google classroom merupakan salah satu media dalam pembelajaran daring yang dilakukan selama pandemic covid 19. Tujuan kegiatan ini adalah memberikan pengetahuan dalam mengelola kelas dengan memanfaatkan google classroom sebagai media pembelajaran, Membantu mitra dalam proses belajar mengajar secara daring. Metode Pelaksanaan program ini terdiri dari kegiatan ceramah, praktek, diskusi dan evaluasi program melalui observasi dan kuesioner. Pelatihan ini diikuti oleh 17 peserta yang terdiri dari guru-guru SMP Kemala Bhayangkari 1 Medan. Setelah dilakukan pelatihan selama lebih dari 90 menit, para guru-guru dapat mengelola kelas di google classroom seperti membuat kelas online, memberikan materi, membuat absensi, memberikan tugas dan memberikan penilaian hasil belajar siswa. Dari hasil kuesioner yang diperoleh bahwa ada $82 \%$ guru menggunakan aplikasi whatsapp sebagai media pembelajaran daring dan $18 \%$ guru yang menggunakan google classroom. Dan hasil pelatihan pengelolaan kelas yang dilakukan diperoleh hasil $15 \%$ mengatakan mudah, $62 \%$ sedang dan $23 \%$ sulit.
\end{abstract}

Kata Kunci: Google Classroom, Pengelolaan Kelas, Media Pengajaran

\begin{abstract}
Google classroom is one of the media in online learning that was carried out during the Covid 19 pandemic. The purpose of this activity is to provide knowledge in managing classes by utilizing google classroom as a learning medium, helping partners in the teaching and learning process online. Methods of implementation of this program consist of lectures, practice, discussion and program evaluation through observation and questionnaires. This training was attended by 17 participants consisting of teachers of SMP Kemala Bhayangkari 1 Medan. After training for more than 90 minutes, teachers can manage classes in google classrooms such as creating online classes, providing materials, making attendance, assigning assignments and assessing student learning outcomes. From the results of the questionnaire obtained that there are $82 \%$ of teachers using the WhatsApp application as an online learning medium and $18 \%$ of teachers using Google classroom. And the results of the classroom management training carried out showed that $15 \%$ said it was easy, $62 \%$ moderate and $23 \%$ difficult.
\end{abstract}

Keywords: Google Classroom, Managing Classes, Teaching tools

\section{Pendahuluan}

Pada saat ini dunia sedang mengalami krisis pandemic virus corona atau Covid-19. Pada bulan maret 2020, virus tersebut melanda di Negara Indonesia ini. Covid-19 adalah penyakit 
menular yang disebabkan oleh jenis coronavirus yang baru ditemukan. Walaupun lebih banyak menyerang ke lansia, virus ini sebenarnya bisa juga menyerang siapa saja, mulai dari bayi, anak-anak, hingga orang dewasa. Virus corona ini bisa menyebabkan ganguan ringan pada sistem pernapasan, infeksi paru-paru yang berat, hingga kematian. Dengan terjadinya wabah Covid-19 telah melumpukan kegiatan disemua bidang, terutama dibidang pendidikan.

Menteri Pendidikan dan Kebudayaan (Mendikbud) Nadiem Anwar Makarim menerbitkan Surat Edaran Nomor 4 Tahun 2020 tentang Pelaksanaan Pendidikan Dalam Masa Darurat Coronavirus Disease (Covid-19). Salah satu pokok penting dalam edaran ini adalah keputusan pembatalan ujian nasional (UN) Tahun 2020. Semenjak pemerintah memberhentikan semua kegiatan pembelajaran tatap muka disekolah-sekolah, agar meminimalkan penyebaran virus covid-19. Pihak sekolahpun mengambil keputusan untuk mengadakan pembelajaran dari rumah agar para peserta didik dapat belajar seperti biasanya.

Menurut Zhang et al., (2004) menunjukkan bahwa penggunaan internet dan teknologi multimedia mampu merombak cara penyampaian pengetahuan dan dapat menjadi alternatif pembelajaran yang dilaksanakan dalam kelas. Pelaksanaan pembelajaran daring membutuhkan adanya fasilitas sebagai penunjang, yaitu seperti smartphone, laptop, ataupun tablet yang dapat digunakan untuk mengakses informasi dimanapun dan kapanpun (Gikas \& Grant, 2013). Pembelajaran daring sangat berbeda dengan pembelajaran seperti biasa, menurut Riyana (2019: 1.14) pembelajaran daring lebih menekankan pada ketelitian dan kejelian peserta didik dalam menerima dan mengolah informasi yang disajikan secara online. Konsep pembelajaran daring memiliki konsep yang sama dengan e-learning. Sedangkan menurut Imania (dalam Henry Aditia Rigianti: 2020) pembelajaran daring merupakan bentuk penyampaian pembelajaran konvensional yang ditunagkan pada format digital melalui internet.

Menurut Arizona (dalam Rosali, 2020) Pembelajaran online yang diterapkan dengan menggunakan media goggle calssroom memungkinkan pengajar dan peserta didik dapat melangsungkan pembelajaran tanpa melalui tatap muka di kelas dengan pemberian materi pembelajaran (berupa slide power point, e-book, video pembelajaran, tugas (mandiri atau kelompok), sekaligus penilaian.

Rosali (2020) mengatakan Keuntungan penggunaan pembelajaran online adalah pembelajaran bersifat mandiri dan interaktivitas yang tinggi, mampu meningkatkan tingkat ingatan, memberikan lebih banyak pengalaman belajar, dengan teks, audio, video dan animasi yang semuanya digunakan untuk menyampaikan informasi, dan juga memberikan kemudahan menyampaikan, memperbarui isi, mengunduh, para siswa juga bisa mengirim email kepada siswa lain, mengirim komentar pada forum diskusi, memakai ruang chat, hingga linkvideoconference untuk berkomunikasi langsung.

Dari kutipan diatas dapat disumpulkan bahwa pembelajaran daring merupakan pembelajaran yang dilakukan secara online dan dilakukan dimana saja dan kapan saja, serta dapat digunakan dengan smartphone, laptop dan tablet.

Dalam pembelajaran daring yang saat ini dilakukan sekolah-sekolah yang tidak komersial adalah Google Classroom. Aplikasi Google Classroom menjadi salah satu sarana untuk belajar dan mengajar. Aplikasi ini bisa meningkatkan produktivitas anak serta pengajar walaupun secara virtual. Google Classroom_adalah aplikasi belajar dan mengajar. Semua orang yang berusia di atas 13 tahun dan memiliki akun Google dapat langsung menggunakannya. Untuk menggunakanya, download aplikasi google classroom untuk laptop di Chrome maupun di Hp, seperti Apple iOS dan Android. Biaya yang dipungut adalah gratis.

Berdasarkan hasil penelitian Sabran dan Sabara (dalam Ely Satiyasih Rosali, 2020), pembelajaran dengan menggunakan media google classroom secara keseluruhan cukup efektif dengan tingkat kecenderungan sebesar $77,27 \%$. Hasil penelitian mengenai penggunaan media 
google classroom juga dilakukan oleh Sari pada tahun 2019, dimana hasil penelitiannya mengungkapkan bahwa efektifitas pembelajaran dipengaruhi oleh kemudahan, kemanfaatan, dan kualitas layanan google classroom.

Dari hasil wawancara yang dilakukan dosen kepada wakil kepala sekolah bidang kurikulum pada tanggal 15 Juni 2020, dari mulai bulan maret sampai juni para guru SMP kemala bhayangkari 1 Medan menyatakan bahwa kebanyakan menggunakan WhatsApp sebagai media pembelajaran daring. Dan ada tiga orang guru yang memanfaatkan google classroom sebagai media pembelajaran daring. Dikarenakan para guru kurang mengerti menggunakan google classroom sebagai media pembelajaran.

Menurut Awaludin, dkk (2019) manyatakan bahwa dalam suatu proses belajar mengajar, media pengajaran memiliki peranan yang sangat penting. Media pengajaran adalah komputer agar siswa lebih aktif dalam proses belajar mengajar. Media pengajaran dapat memperjelas penyajian pesan dan informasi sehingga dapat memperlancar dan memudahkan proses belajar.

Dari hasil situasi di atas, jelas bahwa secara umum mitra masih kurang memaksimalkan menggunakan google classroom sebagai media pembelajaran. Dengan demikian permasalahan yang dihadapi para guru-guru dalam pembelajaran daring dapat dirumuskan sebagai berikut: hasil analisis dan evaluasi yang dilakukan mitra dengan tim PKM STMIK Pelita Nusantara Medan, diketahui kelemahan yang dialami oleh mitra sebagai berikut:

1. Guru masih kurang paham dengan teknologi informasi.

2. Guru masih kurang memahami cara penggunaan Google Classroom sebagai media pengajaran daring.

3. Guru masih kurang memahami cara berinteraksi dengan Google Classroom.

\section{Metodologi}

Pelaksanaan PKM ini menjadi tiga bagian yaitu kegiatan ceramah, praktek, dan kegiatan diskusi.

1. Kegiatan Ceramah

Kegitan ini adalah kegiatan tahap awal yang berkaitan dengan google classroom. Menjelaskan bagian-bagian dan manfaat-manfaatnya yang ada di dalam google classroom serta membagikan modul yang telah disusun oleh tim PKM.

2. Kegiatan Praktek

Kegiatan ini termasuk kegiatan inti yang berkaitan pemahaman dan kemampuan mitra pada proses pelatihan google classroom sebagai media pengajaran. Kegiatan ini meliputi praktek dan latihan dalam penggunaan google classroom. Kegiatan praktek meliputi: Pembuatan kelas baru masing-masing guru, kemudian memasukan materi dan video pembelajaran pada tugas kelas serta pembuatan absensi dengan tugas kuis.

Kegiatan latihan meliputi: masing-masing guru membuat kelas baru sesuai degan mata pelajaran yang diampu, kemudian bagaimana memasukkan materi dan video pembelajaran serta membuat absensi dengan tugas kuis.

3. Kegiatan Diskusi

Kegiatan ini adalah kegiatan penutup yang berkaitan dengan hasil praktek yang dilakukan kepada mitra. 
Tabel 1 kegiatan Pelakasanaan PKM

\begin{tabular}{cccll}
\hline Hari & Tanggal & No & \multicolumn{1}{c}{ Waktu } & \multicolumn{1}{c}{ Keterangan } \\
\hline & & 1 & $08.00-08.30$ & $\begin{array}{l}\text { Pembukaan, penjelasan tujuan dan tahapan pelaksanaan } \\
\text { kegiatan pelatihan, penyampaian tentang google classroom } \\
\text { sebagai media pengajaran. }\end{array}$ \\
& & 2 & $08.30-10.00$ & Kegiatan Praktek \\
Senin & 06 juli & 3 & $10.00-12.00$ & Latihan Pengelolaan google classroom \\
& 2020 & 4 & $12.00-13.30$ & Isoma (Istirahat, Sholat dan makan siang) \\
& & 5 & $13.30-15.00$ & Latihan Pembuatan Absensi, pemberian nilai dan Diskusi \\
& 6 & $15.00-15.30$ & Penutupan \\
\hline
\end{tabular}

\section{Hasil dan Pembahasan}

\section{A. Hasil}

\section{Tahap Persiapan}

Pada tahap ini tim PKM berkordinasi persiapan pelatihan dengan kepala sekolah SMP Kemala Bhayangkari 1 Medan. Hasil yang disepakati untuk melakukan kegiatan pelatihan adalah tanggal 6 juli 2020, dengan 17 peserta. Pada kegiatan berikutnya tim PKM berkoordinasi dalam penyusunan modul yang akan diberikan.

\section{Tahap Pelaksanaan}

Kegiatan ini dilaksanakan sesuai dengan jadwal yang telah direncanakan. Jumlah peserta adalah 17 orang dan yang hadir hanya 13 peserta. Penyampaian materi pelatihan disampaikan oleh Awaludin Fitra, S.Pd., M.Si tentang penggunaan google classroom. Sebelum melakukan pelatihan, tim PKM mengukur terlebih dahulu penggunaan media pembelajaran daring seperti google classroom dan whatsapp.

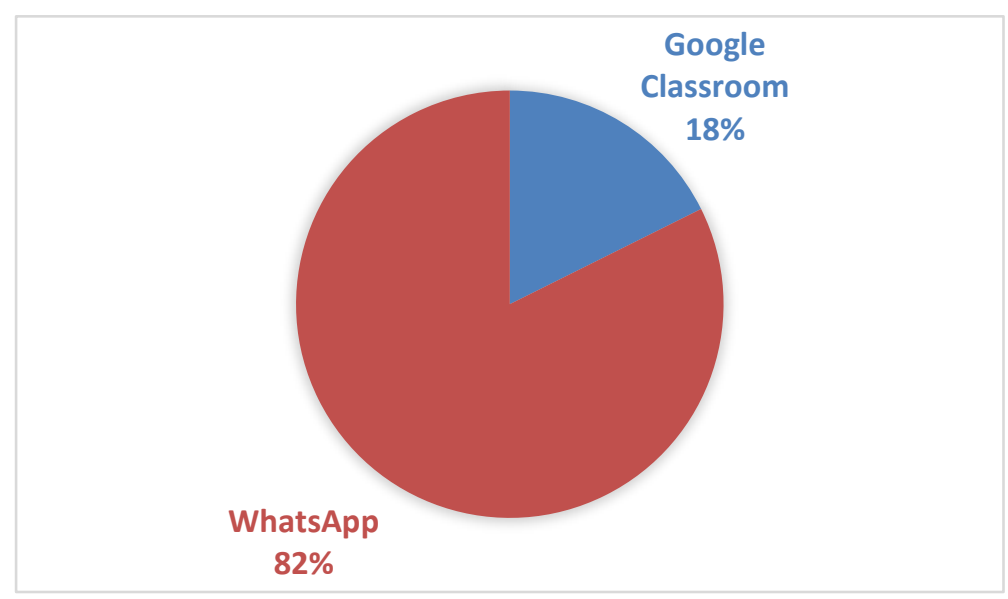

Gambar. 1 Penggunaan Media Pembelajaran daring

Berdasarkan gambar 1 menunjukkan bahwa ada $82 \%$ guru menggunakan aplikasi whatsapp sebagai media pembelajaran daring dan $18 \%$ guru yang menggunakan google classroom. Google classroom merupakan media pembelajaran online gratis yang dapat digunakan dalam proses belajar mengajar saat ini. Untuk mengakses google classroom ini, kita 
harus memiliki akun google. Menurut Musdholifah dkk (2020) menyatakan Google classroom adalah platform pembelajaran campuran yang dikembangkan oleh google untuk institusi pendidikan yang bertujuan menyederhanakan pembuatan, pendistribusian dan penepatan tugas dengan cara tanpa batas.

Pada tahap pelatihan, para peserta telah memiliki akun google, dikarenakan peserta memiliki handphone android yang terkoneksi langsung ke google. Kemudian membuka google chrome dan ketikkan classroom. Pelatihan dilaksanakan lebih dari 90 menit di laboraturium komputer SMP Kemala Bhayangkari 1 Medan. Pelatihan yang dilakukan berjalan dengan baik dan antusiasme peserta sangat tinggi. Setiap kali mengalami kesulitan dalam pengelolan kelas, peserta langsung memberikan pertanyaan.

Dari hasil pelatihan pengelolaan kelas yang dilakukan diperoleh hasil $15 \%$ mengatakan mudah, $62 \%$ sedang dan $23 \%$ sulit. Terlihat pada gambar dibawah ini:

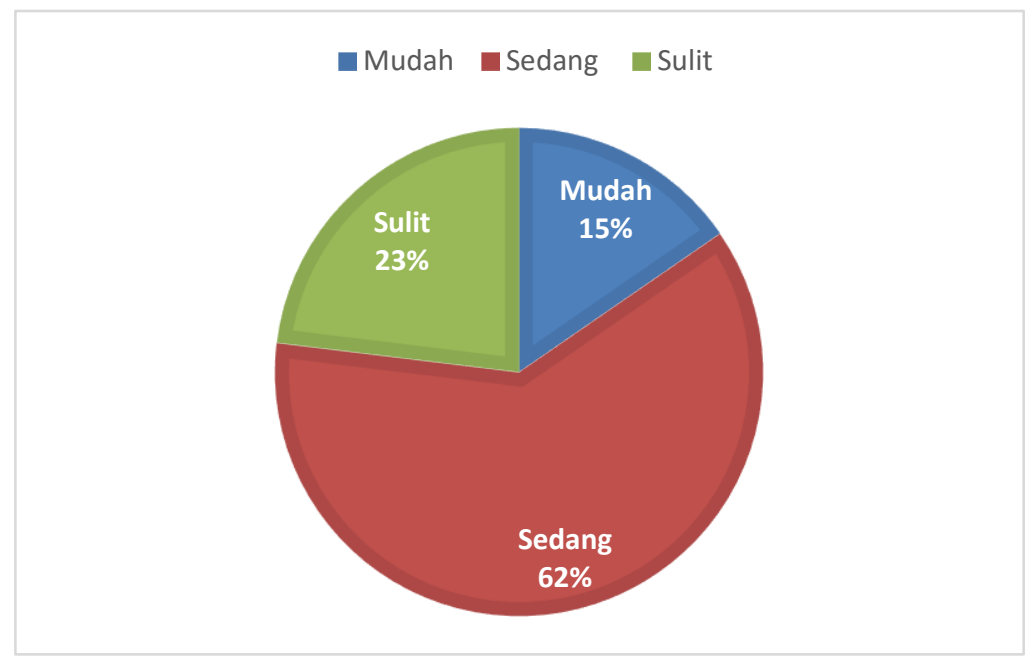

Gambar. 2 Penggunaan Google Classroom

Kesulitan yang dialami peserta sebagai berikut:

1. Membuat absensi dengan menggunakan tugas kuis. Karena tugas kuis menggunkan Google From, dikarenakan banyak bagian-bagian yang kurang paham dalam penggunaannya.

2. Membuat materi pembelajaran yang akan disampai ke peserta didik serta memilih video pembelajaran yang sudah ada.

Dalam pengelolaan kelas guru memiliki kemampuan mengorganisasi pembelajaran. Kemampuan yang telah dimiliki seorang guru dapat mengurutkan materi yang disampaikan secara sistematis sehingga mudah dipahami oleh peserta didik. Menurut Mulyasa (dalam Rigianti, 2020) menyatakan kemampuan mengorganisasikan materi terdiri dari dua tahap, yaitu memilih materi pembelajaran dan menyusun materi pembelajaran. Ketika pembelajaran berlangsung secara tatap muka, guru sudah terbiasa untuk melakukan pengorganisasian pembelajaran.

Dalam pembelajaran daring ini juga para guru juga harus menyusun materi yang akan disampaikan secara sistematis, agar peserta didik mudah memahami materi dalam proses belajar mengajar. Guru juga harus memantau siswa melalui whatsapp agar peserta didik mudah 
mendapatkan informasi-informasi yang akan disampaikan sebelum pembelajaran dan sebaliknya para peserta didik dapat memberikan informasi jika berhalangan dalam proses belajar mengajar.

\section{B. Pembahasan}

Dalam proses belajar mengajar secara daring dengan menggunakan google classroom, para peserta harus memiliki akun google terlebih dahulu. Dari hasil data yang diperoleh para peserta semuanya memiliki akun google, karena para peserta memiliki smartphone. Akan tetapi peserta yang menggunakan google classroom media pembelajaran daring adalah 3 orang atau $18 \%$. Dan yang menggunakan whatsapp sebagai media pembelajaran daring adalah 14 orang atau $82 \%$.

Setelah dilakukan pelatihan peserta diberikan praktek cara mengelola kelas pada google classroom. mulai dari pembuatan kelas baru, memberikan materi, membuat video pembelajaran atau mencari video pembelajaran yang ada di youtube, membuat absensi, memberikan tugas dan memberikan penilaian. Dalam proses pelatihan diperoleh hasil penggunaan google classroom yang menyatakan mudah adalah $15 \%$, sedang $62 \%$, sulit $23 \%$. Kesulitan yang dialami oleh peserta adalah cara membuat absensi dengan menggunakan tugas kuis. Dikarenakan banyak bagian-bagian yang harus digunakan dalam proses pembuatan absensi. Dan pemberian nilai tugas yang dikirim oleh siswa. Para guru juga harus membuat materi yang akan disampaikan secara sistematis agar peserta didik dengan mudah memahami materinya.

Keuntungan menggunakan google classroom adalah: 1). Para guru dapat mengajar dimana saja. 2). Ruang penyimpanan google classroom akan disimpan kedalam google drive. Artinya jika kita memberikan materi, dan siswa mengirimkan tugas, maka ruang penyimpanan tidak akan tersimpan didalam smartphone, melainkan tersimpan digoogle drive yang kita miliki.

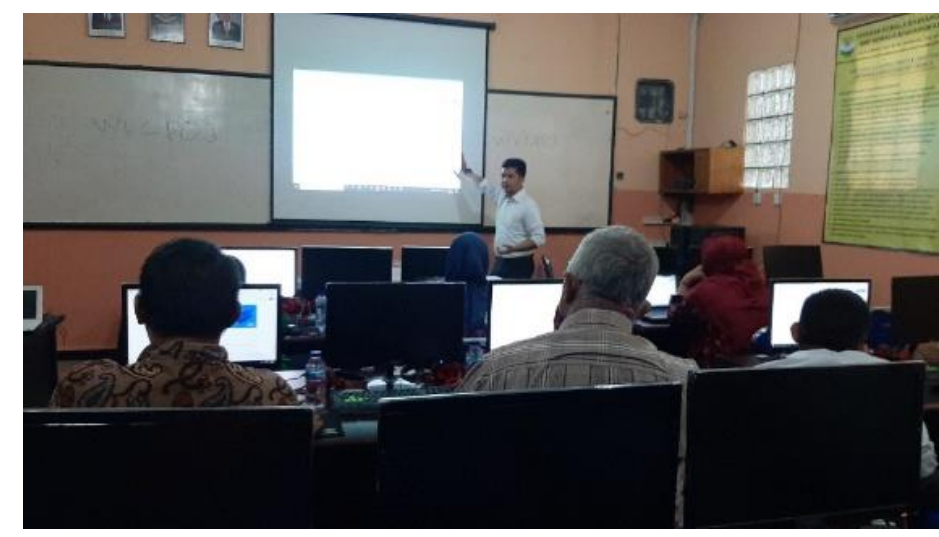

Gambar. 3 Menjelaskan tentang GC 


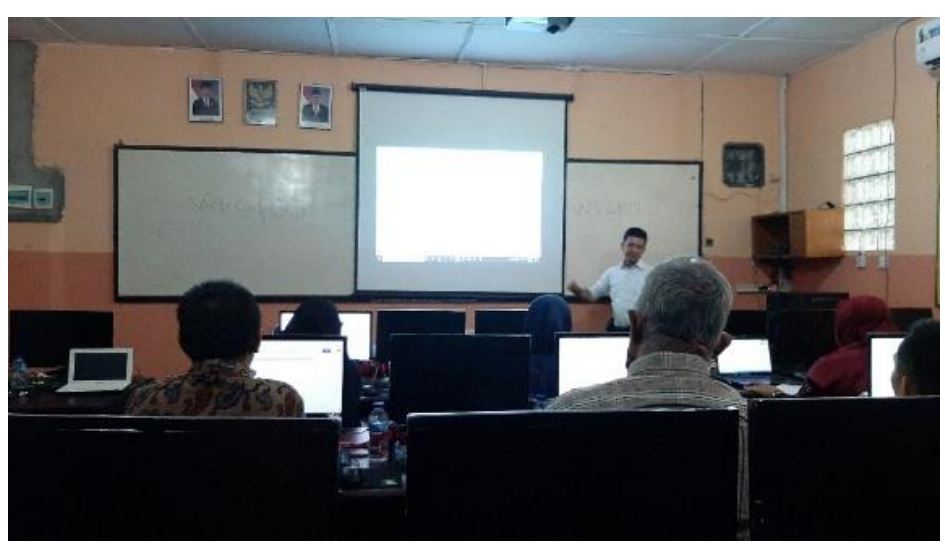

Gambar. 4 Menjelaskan bagian pada GC

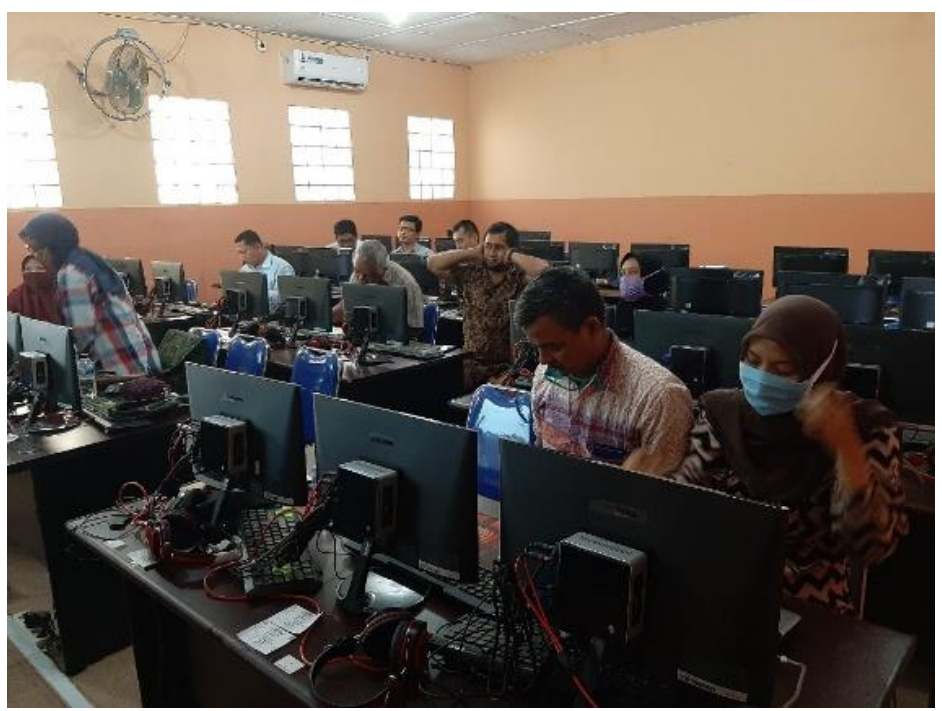

Gambar. 5 langkah cara pengelolaan GC

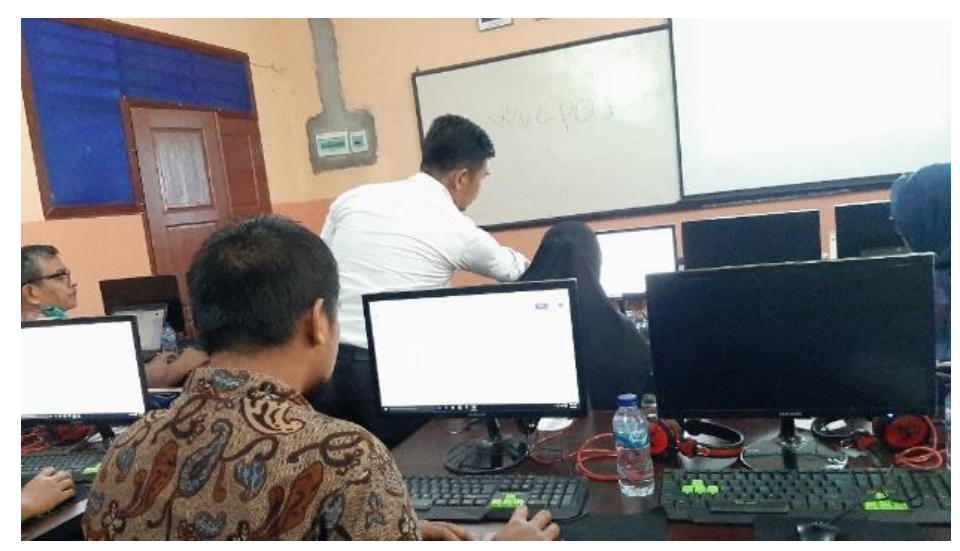

Gambar. 6 Kegiatan Latihan 


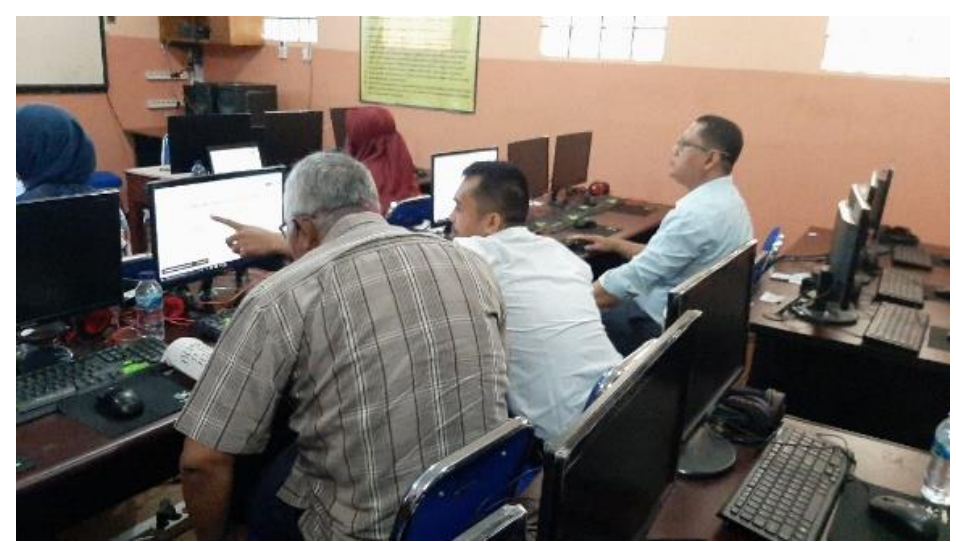

Gambar. 7 Kegiatan diskusi dan Latihan

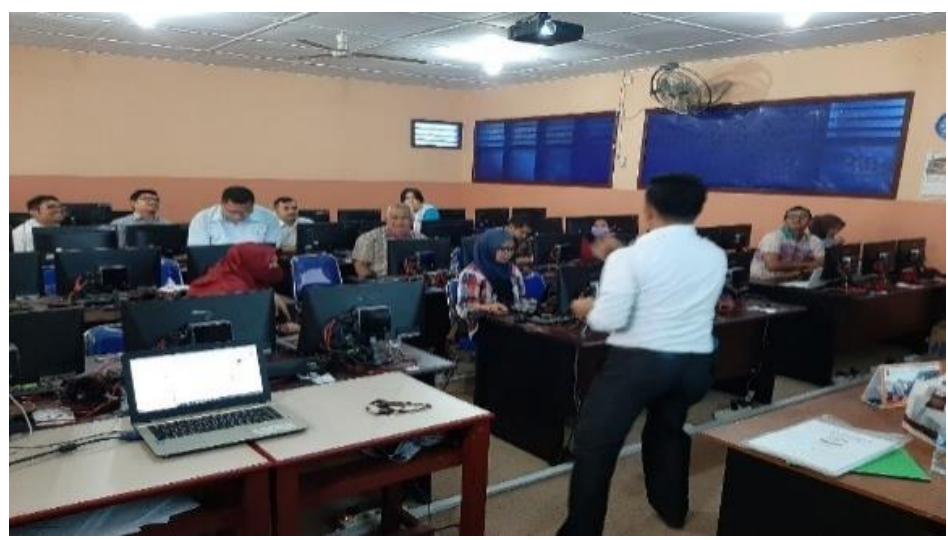

Gambar. 8 Kegiatan diskusi

\section{Kesimpulan}

Melalui kegiatan Pengabdian Kepada Masyarakat ini para guru di SMP Kemala Bhayangkari 1 Medan mampu mengelola kelas di google class seperti membuat kelas baru dan memberikan nama kelas tersebut. Guru juga dapat menyapa siswa di dalam forum, guru juga dapat memberikan materi didalamnya dengan menggunakan tugas kelas. Pada tugas kelas juga para guru dapat mengelola pembuatan absensi dengan bantuan tugas kuis yang berbentuk google formulir, serta guru dapat memberikan arahan agar siswa dapat mengirimkan foto siswa yang sedang mengikuti pembelajaran daring. Dalam pengelolaan kelas disaran oleh TIM PKM, para guru lebih baik menggunakan laptop atau PC dikarenakan lebih efektif dalam pengiriman materi yang telah dibuat oleh guru-guru dan pembuatan absensi dengan tugas kuis. Guru juga dapat menggunakan smartphone jika materi dan absensi telah selesai dibuatkan dari laptop atau PC, dan para guru juga dapat menggunakan WA dalam pemberian arahan dalam proses belajar mengajar secara daring.

\section{Ucapan Terima Kasih}

Syukur Allhamdulillah penulis ucapkan kehadirat Allah SWT, yang telah menitipkan ilmu serta melimpahkan rahmat dan hidayahNya sehingga penulis dapat menyelesaikan 
Pengabdian Kepada Masyarakat. Pada kesempatan ini penulis menyampaikan terima kasih kepada:

1. Bapak DR. Jhon Foster Marpaung dan Ibu Rita Zahra, MM. selaku pimpinan yayasan demokrat cemerlang.

2. Bapak Hengky Tamando Sihotang, S.Kom., M.Kom, selaku Ketua STMIK Pelita Nusantara Medan.

3. Agust, S.Kom, M.Kom, selaku ketua Prodi Teknik Informatika STMIK Pelita Nusantara Medan.

4. Ibu Risma Martuani Sormin, selaku Ibu Ketua Yayasan Kemala Bhayangkari Daerah Sumatera Utara.

5. Ibu Rini Adilla Ulfa, S.Pd., M.Hum., selaku Kepala Sekolah SMP Kemala Bhayangkari 1 Medan.

Saya mengucapkan terima kasih yang sebesar-besarnya, yang telah memberikan dukungan baik moril dan material dalam pelaksanaan pengabdian kepada masyarakat berjalan dengan baik dan lancar. Penulis berupaya semaksimal mungkin dalam penyelesaian penulisan pengabdian ini, namun penulis menyadari masih banyak kelemahan baik dari segi isi maupun tata bahasa, untuk itu penulis mengharapkan saran dan kritik yang bersifat membangun dari pembaca demi sempurnanya pengabdian ini. Kiranya isi skripsi ini bermanfaat dalam memperkaya khasanah ilmu pendidikan.

\section{Daftar Pustaka}

Arizona, Kurniawan. et.all. (2020). Pembelajaran Online Berbasis Proyek Salah Satu Solusi Kegiatan Belajar Mengajar di Tengah Pandemi Covid-19. Jurnal Ilmiah Profesi Pendidikan. Volume 5 No 1 Mei 2020. (Online) Tersedia :https://jipp.unram.ac.id/index.php/jipp/article/download/111/99.

Awaludin Fitra, Yulia Utami, Martua Sitorus (2019). Pemanfaatan Aplikasi microsoft Mathematics Terhadap Hasil Belajar Siswa SMP Kemala Bhayangkari 1 Medan. http://ejurnal.pelitanusantara.ac.id/index.php/mantik/article/view/564. Hal 54-64.

Gikas, J., \& Grant, M. M. (2013). Mobile computing devices in higher education: Student perspectives on learning with cellphones, smartphones \& social media. Internet and Higher Education. Vol. 19 Pages 18-26.

Rigianti. (2020). Kendala Pembelajaran Daring Guru Sekolah Dasar Di Kabupaten Banjarnegara. (https://journal.upy.ac.id/index.php/es/article/view/768).

Musdholifah, Dewie Tri Wijayati Wardoyo, Sri Setyo Iriani, Ulil Hartono, Achmad Kautsar. (2020). Pengembangan Media Pembelajaran Kelas Online Untuk Guru Sma Di Kabupaten Magetan. (https://ejurnal.ikippgribojonegoro.ac.id/index.php/JABDIPAMAS/article/view/673).

Riyana, C. (2019). Produksi Bahan Pembelajaran Berbasis Online. Universitas Terbuka

Zhang, et al. (2004). Can e-learning replace classroom learning? Communications of the ACM.Vol. 47 No.5.

Ely Satiyasih Rosali. (2020). Aktifitas Pembelajaran Daring Pada Masa Pandemi Covid-19 di Jurusan Pendidikan Geografi Universitas Siliwangi Tasikmalaya. http://jurnal.unsil.ac.id/index.php/geosee/article/view/1921. 